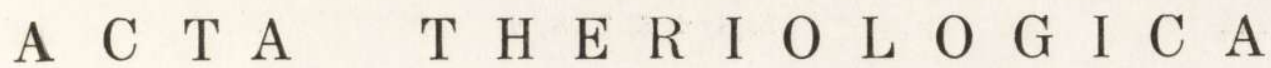

VOL. $20, \_31: 443-457$.

August, 1975

Lucjan S Y C H \& Barbara S Y C H

\section{Arranging of Allometry Coefficients for Growth Gradients Studies}

[With 2 Tables]

\begin{abstract}
The growth of skull was analysed in terms of allometry and correlation on laboratory specimens of Lagurus lagurus, whose dates of birth and death were known. A new method of treating the divergencies from simple allometry was offered. It consists of an analysis of all the possible allometric combinations of characters. Within each group the permutations of the values of $\alpha$ were arranged in ascending order. In this way particular characters were marshalled and their neighbourhood remained unchanged irrespective of permutations. Sets of characters having the same mutual neighbourhood are determined by the gradient arrangement of allometric values. In this aspect the gradients change continuously with growth and, consequently, in the case of $L$. lagurus none of the sets of characters in successive age groups remained complete. Correlations were compared by the gathering into a matrix of coefficients $r$, calculated for all the possible pairs of characters in all of the age groups. The values of $r$ were analysed with regard to the durability of relationships between characters in the course of life, or the lack of such relationships at all.
\end{abstract}

\section{INTRODUCTION}

The central idea of the study was to treat the process of growth of the skull as a result of the action of integrating mechanisms, which cause the formation of the final morphological features of the skull, for the activity of inductive mechanisms, resulting in the formation of main organs, comes to an end long before the pri- and postnatal period and the further development proceeds under the control of integrating mechanisms, whose sphere of activity is gradually reduced. The results produced by the activity of the mechanisms of morphological integration (cf. Ols on \& Miller, 1958) can be determined quantitatively by computing the inequality of rate increases in dimensions and the changes in and degree of their mutual relations in different stages of life. In the early stage most characters undergo changes, generally at various rates. 
Inequality in the rate of changes is relatively easily perceived when divergencies from simple growth allometry are investigated. The specific nature of allometric changes in characters has been traditionally studied by determining the curvilinear dependence of characters selected on one fixed character, e.g. the relationship between the measurements of a body part and the body size. This is a great simplification of the problem of growth as a time-spatial phenomenon, which apart from this has already been simplified by the selection of convenient measuring points for delermining the characters. A different method of treatment of the divergencies from simple allometry is offered in the present paper. It consists of an analysis of all the possible allometric combinations of characters.

The purpose of this paper is to analyse growth of the skull in terms of allometry and correlation and to make an attempt to interpret the results obtained from the biological point of view. Classificatory possibilities arising from the use of the so-called inocular characters, i.e. the characters of groups of individuals, are also considered. The choice of a mammalian species for our study was of minor importance; steppe lemming as an animal bred in the laboratory offered convenient material.

\section{MATERIAL AND METHOD}

Skulls of steppe lemmings Lagurus lagurus (P a 11 a s, 1773) bred at the Mammals Research Institute at Białowieża were used for study. Most of the material had been used for the work on body variability in Lagurus carried out by Gę bc zy ńska (1967). The dates of birth and death of each specimen were known. The analysis of correlations was carried out in four age groups: Group $A$ included 25 specimens in their 2nd month, Group B 48 specimens $3-7$ months old, Group $C$ 29 specimens aged 8-12 months, and Group D 29 specimens older than 12 months. The allometry was analysed in five equal sections of the whole growth period (marked with Arabic figures from 1 to 5 ). The sections do not coincide accurately with the age groups adopted for the correlation studies because of the procedure of smoothing the growth curve. This however has no effect on the results. The following ten skull dimensions were chosen:

$X_{1}$ interorbital constriction (IC)

$X_{2}$ zygomatic breadth, greatest distance $(Z y B)$

$X_{3}$ brain-case breadth, distance between outermost points of the auditory capsules $(B c B)$

$\mathrm{X}_{4}$ maxillary diastema length $(M x D L)$

$X_{5}$ maxillary tooth-row length, maximum extent of alveoli (MxTRL)

$X_{6}$ mandibular diastema length $(M d D L)$

$X_{7}$ mandibular tooth-row length, maximum extent of alveoli (MdTRL)

$X_{8}$ skull length, from the posterior border of the alveolus of the upper incisor

to the furthermost point of the posterior convexity of the cranium (SL)

$X_{9}$ frontal-palatal skull heigth, measured between the first and second molar (SH)

$\mathrm{X}_{10}$ brain-case height measured on the lateral aspect $(\mathrm{BcH})$ 
Measurements were made on photographs (magnification $9 \times$ ), of four aspects of each skull. The same scale for the whole of material was used. The numerical values of measurements were used without being converted into absolute values in calculations. According to our experience, the measuring of skulls on their photographs allowed the reduction of measuring error to about one-third.

Allometric information concerning the skull growth was obtained by comparing each character (dimension) with each of the others within particular age groups. The increments in the value of each dimension at constant intervals were calculated separately and growth coefficients $k$ were obtained for five equal periods. The value of $k$, which is the coefficient of growth rate in the normal growth equation for one character over time $t\left(X_{t}=X_{0}+k t\right)$, was obtained from the differences between the values of a given dimension in neighbouring age groups. Since the portions of the growth curve in each age group must be treated as curve segments of a logarithmic curve, the above-mentioned differences between dimensions were not calculated from the values of these dimensions but from their logarithms. The quotient of two coefficients $k$ obtained for two different dimensions in the same age group is the coefficient of their allometry in this group ( $\mathrm{Simpson}, \mathrm{Roe} \&$ Lewontin, 1960). The values of an exponent in the allometric equation of two characters $\alpha, Y=b X_{\alpha}$. were computed for all possible pairs formed from the ten dimensions in five equal time intervals. This mode of treating allometric changes seems more descriptive than is the conventional confrontation of selected dimensions with one and the same character, e.g. body size, in allometric equations. On obtaining a complete set of coefficients of allometry, we calculated skull growth gradients.

Such a use of allometry is theoretically justified by the significance of the coefficient $\alpha$, for here we are concerned with the following possibilities: 1) if $\alpha$ is sufficiently constant throughout lifetime, the pair of dimensions constitutes a typical perfect allometric relationship in which their ratio changes in a defined and continuous way governed by the classic equation $\left.Y=b X_{c} ; 2\right)$ if $\alpha$ undergoes fluent or step changes in the course of growth, they reflect deviations from simple allometry. These deviations are very frequent and the growth of individual parts of the skull can much more frequently be considered in the aspect of deviation than in the aspect of the fitting of some characters to simple allometric equations.

The values of $\alpha$, which were very variable, were analysed not only in groups differing in age but also in matrices specially constructed for this purpose. Knowing $\alpha$ for each pair of characters in each age group, we constructed matrices by setting together one dimension with all the remaining ones successively in such a way that the values of $\alpha$ were 
arranged in ascending order (Table 2). Than the values of particular characters, corresponding to the increasing values of $\alpha$, were automatically marshalled according to the conditions arising from the ascending order of $\alpha$ in each table. The order of characters in one table was subsequently compared with that in the other tables.

The following possibilities of analysis of the coefficient $\alpha$ were here noted: 1) the investigation of regularity with which some characters keep their neighbourhood unchanged in different permutations within one age group: 2) the investigation of regularity with which the mutual neighbourhood of characters is kept throughout the age groups and the sortingout of clusters of characters persisting over lifetime or, at least, its part; 3 ) the search for uniform or very close values of $\alpha$ (differences not exceeding 0.05 ) in the same permutations of characters in different age groups (the selection of the same permutations makes it possible to refer allometry to the same character); and 4) the search for isometry of characters persisting for fairly long period of time, if there is any, or for cases in which $\alpha$ equals or is close to 1 .

The cases in which $\alpha$ is equal to 0 are fairly numerous in the results of our study and then $Y=b X^{0}$ or $X=b Y^{0}$; hence $Y=b$ or $X=b$. This indicates the occurrence of such pairs of dimensions that there is no increase in $k$ for these dimensions over a period of time, which results in the fact that the quotient of two coefficients $k$ (constituting constant $\alpha$ ) is equal to 0 .

Correlations were examined by comparing correlation coefficients $r$ calculated for all the possible pairs of characters. The values of $r$ (converted into Fisher's $z$ ) were considered with regard to the constancy of the relationships between characters over the life span (in the four above-mentioned groups: $A, B, C$ and $D$ ) or to the lack of any relationships at all.

\section{RESULTS}

The correlation coefficients $r$, form sets that can generally be included in one of the following categories: 1) pairs of characters lacking relationship; in all age groups $(A, B, C, D)$ or having a very loose relationship, close to the limit of significance, in one or two groups; 2) pairs of characters showing a distinct relationship in at least two age groups, in no case exceeding $0.70 ; 3$ ) pairs of characters the relationship between which is expressed by a value exceeding 0.70 in at least one age group (Table 1).

The following pairs of characters have no significant relationship in any of the age groups: $X_{1}-X_{2}, X_{1}-X_{3}, X_{1}-X_{4}, X_{1}-X_{5}, X_{1}-X_{6}, X_{1}-X_{7}$, 
$X_{1}-X_{8}, \quad X_{1}-X_{9}, \quad X_{1}-X_{10}, \quad X_{2}-X_{6}, \quad X_{3}-X_{6}, \quad X_{4}-X_{5}, X_{4}-X_{6}, X_{5}-X_{6}$, $X_{5}-X_{10}, X_{6}-X_{9}, X_{6}-X_{9}, X_{6}-X_{10}, X_{7}-X_{9}, X_{7}-X_{10}$.

A distinct relationship between dimensions in at least two age groups

Table 1

The correlation coefficients $r$ of ten skull characters $X_{1}-X_{10}$ as compared in four successive age groups $A, B, C$, and $D$.

\begin{tabular}{|c|c|c|c|c|c|c|c|c|c|c|}
\hline$X_{2}$ & $X_{3}$ & $X_{4}$ & $X_{5}$ & $X_{6}$ & $X_{7}$ & $X_{8}$ & $X_{9}$ & $X_{10}$ & & \\
\hline \multirow[t]{9}{*}{$\begin{array}{l}0.41 \\
0.06 \\
0.07 \\
0.16\end{array}$} & $\begin{array}{l}0.28 \\
0.13 \\
0.33 \\
0.29\end{array}$ & $\begin{array}{l}0.36 \\
0.20 \\
0.00 \\
0.21\end{array}$ & $\begin{array}{r}0.03 \\
0.00 \\
-0.11 \\
0.19\end{array}$ & $\begin{array}{r}-0.22 \\
0.27 \\
-0.11 \\
0.35\end{array}$ & $\begin{array}{r}0.02 \\
0.19 \\
0.21 \\
-0.06\end{array}$ & $\begin{array}{l}0.13 \\
0.03 \\
0.19 \\
0.32\end{array}$ & $\begin{array}{l}0.22 \\
0.17 \\
0.31 \\
0.41\end{array}$ & $\begin{array}{l}0.02 \\
0.19 \\
0.46 \\
0.16\end{array}$ & $\begin{array}{l}A \\
B \\
C \\
D\end{array}$ & $X_{1}$ \\
\hline & $\begin{array}{l}0.77 \\
0.63 \\
0.32 \\
0.69\end{array}$ & $\begin{array}{l}0.70 \\
0.50 \\
0.43 \\
0.30\end{array}$ & $\begin{array}{l}0.46 \\
0.58 \\
0.38 \\
0.21\end{array}$ & $\begin{array}{r}-0.07 \\
0.31 \\
0.16 \\
0.20\end{array}$ & $\begin{array}{l}0.56 \\
0.45 \\
0.35 \\
0.61\end{array}$ & $\begin{array}{l}0.60 \\
0.73 \\
0.57 \\
0.41\end{array}$ & $\begin{array}{l}0.71 \\
0.57 \\
0.47 \\
0.46\end{array}$ & $\begin{array}{l}0.46 \\
0.50 \\
0.24 \\
0.33\end{array}$ & $\begin{array}{l}A \\
B \\
C \\
D\end{array}$ & $X_{2}$ \\
\hline & & $\begin{array}{l}0.80 \\
0.37 \\
0.29 \\
0.44\end{array}$ & $\begin{array}{r}0.48 \\
0.47 \\
0.01 \\
-0.07\end{array}$ & $\begin{array}{r}-0.13 \\
0.26 \\
0.10 \\
0.11\end{array}$ & $\begin{array}{l}0.57 \\
0.27 \\
0.33 \\
0.41\end{array}$ & $\begin{array}{l}0.81 \\
0.72 \\
0.59 \\
0.54\end{array}$ & $\begin{array}{l}0.76 \\
0.53 \\
0.57 \\
0.48\end{array}$ & $\begin{array}{l}0.66 \\
0.60 \\
0.27 \\
0.46\end{array}$ & $\begin{array}{l}A \\
B \\
C \\
D\end{array}$ & $X_{3}$ \\
\hline & & & $\begin{array}{r}0.36 \\
0.24 \\
0.16 \\
-0.03\end{array}$ & $\begin{array}{r}-0.15 \\
0.28 \\
0.32 \\
0.03\end{array}$ & $\begin{array}{l}0.55 \\
0.32 \\
0.30 \\
0.19\end{array}$ & $\begin{array}{l}0.89 \\
0.79 \\
0.80 \\
0.79\end{array}$ & $\begin{array}{l}0.67 \\
0.55 \\
0.41 \\
0.22\end{array}$ & $\begin{array}{l}0.50 \\
0.41 \\
0.26 \\
0.20\end{array}$ & $\begin{array}{l}A \\
B \\
C \\
D\end{array}$ & $X_{4}$ \\
\hline & & & ' & $\begin{array}{r}0.10 \\
0.10 \\
-0.04 \\
0.31\end{array}$ & $\begin{array}{l}0.59 \\
0.61 \\
0.35 \\
0.07\end{array}$ & $\begin{array}{l}0.56 \\
0.52 \\
0.34 \\
0.04\end{array}$ & $\begin{array}{l}0.37 \\
0.42 \\
0.18 \\
0.41\end{array}$ & $\begin{array}{r}0.19 \\
0.22 \\
0.29 \\
-0.20\end{array}$ & $\begin{array}{l}A \\
B \\
C \\
D\end{array}$ & $X_{5}$ \\
\hline & & & & & $\begin{array}{r}-0.03 \\
0.19 \\
0.00 \\
0.09\end{array}$ & $\begin{array}{r}-0.08 \\
0.30 \\
0.31 \\
0.18\end{array}$ & $\begin{array}{r}0.03 \\
0.20 \\
-0.04 \\
0.27\end{array}$ & $\begin{array}{r}0.15 \\
0.37 \\
-0.03 \\
0.41\end{array}$ & $\begin{array}{l}A \\
B \\
C \\
D\end{array}$ & $X_{6}$ \\
\hline & & 1 & & & & $\begin{array}{l}0.73 \\
0.43 \\
0.51 \\
0.29\end{array}$ & $\begin{array}{l}0.32 \\
0.42 \\
0.32 \\
0.36\end{array}$ & $\begin{array}{l}0.33 \\
0.34 \\
0.32 \\
0.39\end{array}$ & $\begin{array}{l}A \\
B \\
C \\
D\end{array}$ & $X_{7}$ \\
\hline & & & & & & & $\begin{array}{l}0.63 \\
0.68 \\
0.58 \\
0.47\end{array}$ & $\begin{array}{l}0.49 \\
0.62 \\
0.41 \\
0.48\end{array}$ & $\begin{array}{l}A \\
B \\
C \\
D\end{array}$ & $X_{8}$ \\
\hline & & & & & & & & $\begin{array}{l}0.63 \\
0.65 \\
0.60 \\
0.39\end{array}$ & $\begin{array}{l}A \\
B \\
C \\
D\end{array}$ & $X_{9}$ \\
\hline
\end{tabular}

occurs in the following pairs: $X_{2}-X_{7}, X_{2}-X_{10}, X_{3}-X_{5}, X_{3}-X_{7}, X_{3}-X_{10}$, $X_{4}-X_{7}, \quad X_{4}-X_{9}, \quad X_{4}-X_{10}, X_{5}-X_{7}, X_{5}-X_{8}, \quad X_{5}-X_{9}, X_{7}-X_{10}, X_{8}-X_{9}$, $X_{8}-X_{10}, X_{9}-X_{10}$.

The following pairs of dimensions are highly correlated in at least one 


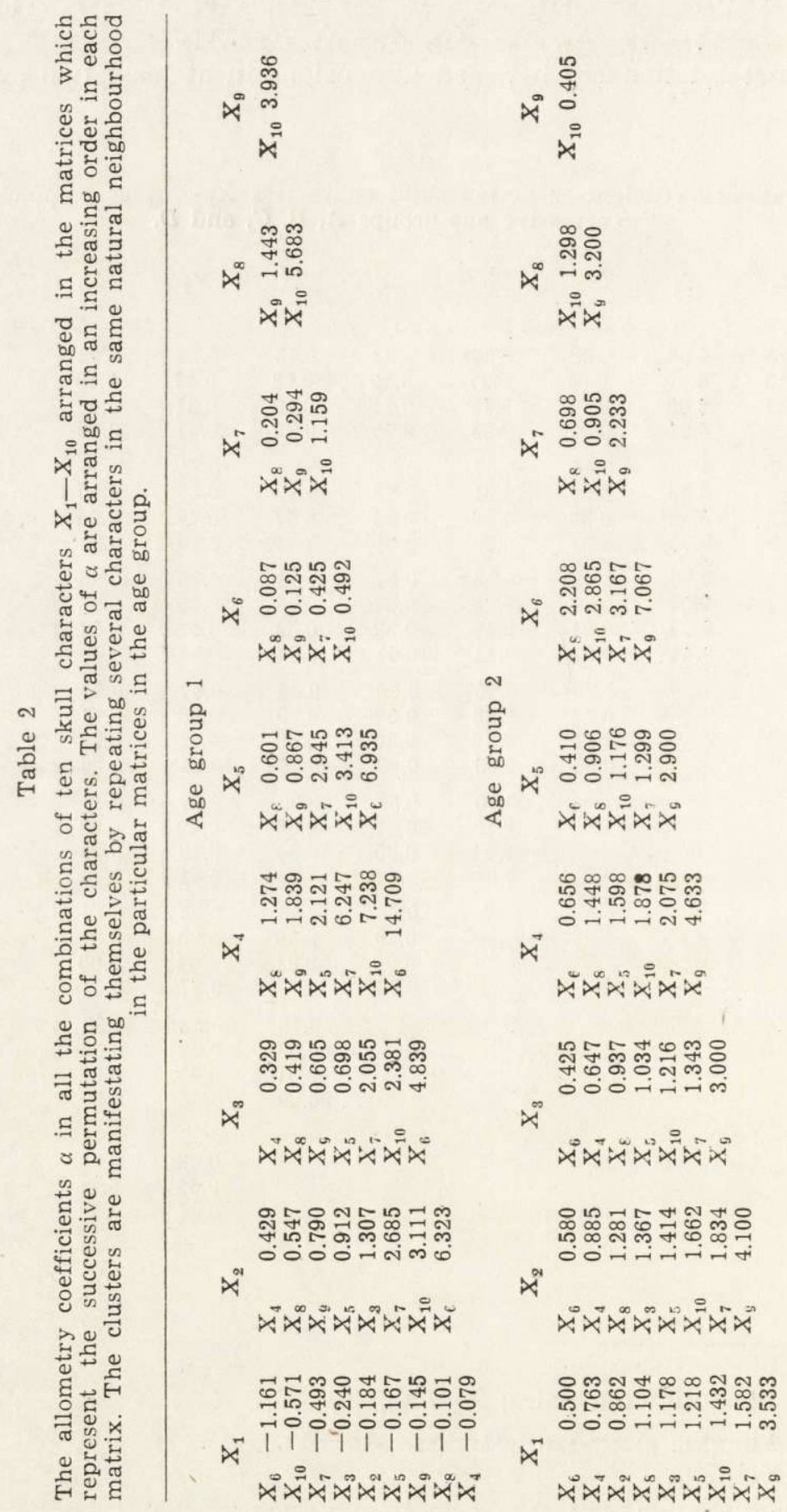




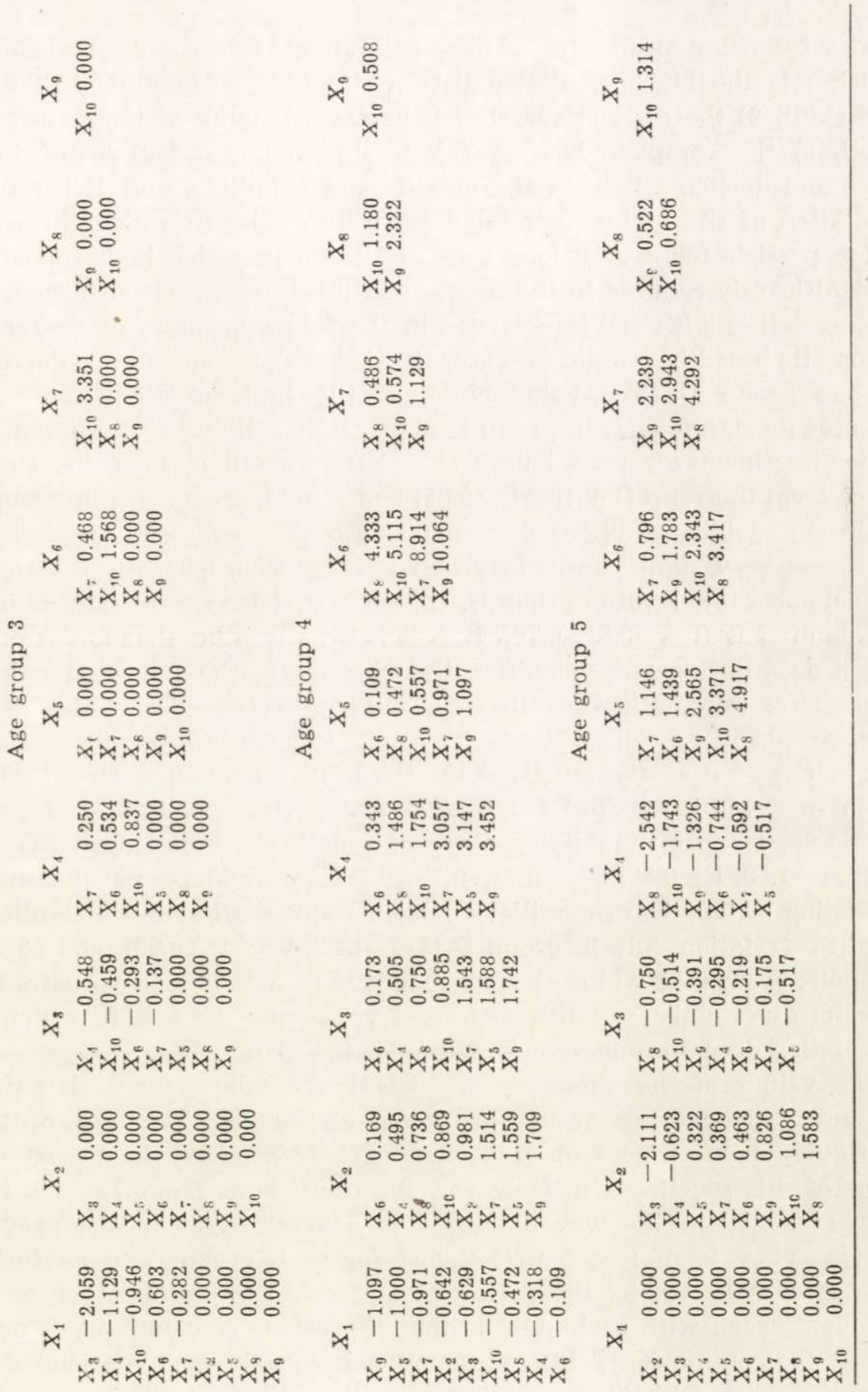


age group: $X_{2}-X_{3}, X_{2}-X_{4}, X_{2}-X_{8}, X_{2}-X_{9}, X_{3}-X_{4}, X_{3}-X_{8}, X_{3}-X_{9}$, $X_{4}-X_{8}, X_{7}-X_{8}$.

The following properties of these pairs should be recognized as characteristic: 1) the high correlation between lengths of maxillary diastema and skull, 2) the distinct correlation between lengths of tooth-rows and skull, 3) the complete lack of relationship between lengths of toothrows and diastema both in the maxilla and mandible, and 4) the differentiation of the highly correlated pairs into pairs in which the correlation persists for a very long time and those in which it disappears or is significantly reduced in the second and third group. A conspicuous fall in correlation with age is observed in the following pairs of characters: zygomatic breadth - brain case breadth $\left(X_{2}-X_{3}\right)$, the correlation decreases in age group $C$ to a value close to the limit of significance and restores its significance in group $D(0.05>P>0.02)$; zygomatic breadth upper maxillary diastema length $\left(X_{2}-X_{4}\right)-$ a fall close to the significance level in group $C(0.10>P>0.05)$ and a further decrease in group $D$; brain case width - upper diastema length $\left(X_{3}-X_{4}\right)$ - the correlation decreases very significantly in group $B\left(t_{A B}=2.80,0.02>P>0.001\right)$, and persists at a low level in group $C$, the difference between $C$ and $D$ being nonsignificant $\left(t_{C D}=0.51,0.70>P>0.60\right)$. On the other hand, the correlation does not decrease significantly with age in the following pairs of characters: zygomatic breadth - skull length $\left(X_{2}-X_{8}\right)-\left(t_{B C}=1.25\right.$, $\left.0.30>P>0.20 ; \quad t_{A D}=0.91,0.40>P>0.30\right) ;$ zygomatic breadth - skull height $\left(X_{2}-X_{9}\right)-\left(t_{A B}=0.91,0.40>P>0.30 ; \quad t_{A D}=1.38,0.20>P>0.10\right)$; brain case width - skull height $\left(X_{3}-X_{9}\right)-\left(t_{A C}=1.23,0.30>P>0.20\right.$; $\left.t_{A D}=1.68, P=0.10\right)$; maxillary diastema length - skull length $\left(X_{4}-X_{8}\right)$ $-\left(t_{A D}=1.50, P=0.50 ; t_{C D}^{\prime}=0.42,0.70>P>0.60\right)$. The pair of dimensions consisting of lengths of maxillary diastema and skull shows a significant fall in correlation only in group $D\left(t_{A D}=2.22,0.5>P>0.02\right)$, and so does the pair: brain case width - skull length $\left(X_{3}-X_{8}\right)$. These two pairs may therefore be numbered, with some reserve, among the sets in which the correlation does not undergo changes over the span of life.

The values of the allometry coefficient $\alpha$ obtained for each pair of characters in five age groups are given in Table 2. The lack of their continuity as time goes on is a characteristic property in almost each place of this specification. However, the coefficients from Table 2 have been arranged in the way described in general terms in the previous section. They form five matrices, one for each group. The method of arrangement is simple; the pairs of characters are put together on the principle "each with each « but so that the values of $\alpha$ increase. For instance, the column $X_{1}$ (Table 2) is composed from the combinations of the first dimension with the remaining ones, the values of $\alpha$ being arranged 
in ascending order (N.B., the choices of ascending or descending order is formal in nature) This manner of arrangement determines a certain order of the other nine characters. Another column is formed from the combinations of the second dimension with the order ones, the values of $\alpha$ being again arranged in ascending order, which causes a certain numerical succession of the characters.

The same procedure is repeated for the next dimensions until all the possible combinations of characters have been exhausted. There are naturally more such modes of permutations, e.g. in constructing the abovementioned columns, we can begin with the tenth dimension and set it together with the remaining nine dimensions bearing in mind that the appropriate values of $\alpha$ are to be arranged in ascending order. The fact that irrespective of the permutation performed some characters always occur beside each other in invariable order is a characteristic phenomenon in these matrices. They form clusters of different sizes characterized by the maintenance of always the same mutual neighbourhood of characters. In some permutations the ordering of characters in a cluster is at the most reversed, but nevertheless their neighbourhood remains preserved. Thus, the order of characters in the cluster of $X_{7}, X_{10}$ and $X_{6}$ is repeated with regard to character $X_{2}, X_{3}, X_{4}$ and $X_{5}$ (Table 2, Age group 1) and this cluster occurs twice (with regard to characters $X_{3}$ and $X_{4}$ ) with its composition increased by character $X_{5}$ situated at the beginning $\left(X_{5}, X_{7}\right.$, $X_{10}$ and $X_{6}$ ). Another cluster of age group 1 consists of $X_{4}, X_{8}$ and $X_{9}$ and is repeated in the same order with regard to characters $X_{2}$ and $X_{3}$ (columns $X_{2}$ and $X_{3}$ ), and also to character $X_{1}$, but though in this last case the same mutual neighbourhoods are maintained, their order is reversed. Character $X_{5}$ may also be regarded as part of the cluster $X_{4}$, $X_{8}, X_{9}$ and $X_{10}$. In age group 2 the cluster $X_{10}, X_{7}$ and $X_{9}^{\prime}$ repeats six times, being extended by character $X_{5}$ with regard to characters $X_{1}, X_{2}$ and $X_{3}$ (columns $X_{1}$ and $X_{6}$ ). At the time there is a relationship between characters $X_{6}$ and $X_{4}$, which occur beside each other with regard to characters $X_{1}, X_{2}$ and $X_{3}$ (columns $X_{1}, X_{2}$ and $X_{3}$ ). A similar cluster, consisting of two characters, $X_{8}$ and $X_{10}$, occurs in the same age group with regard to characters $X_{5}, X_{6}$ and $X_{7}$ (columns $X_{5}, X_{6}$ and $X_{7}$ ). It is difficult to distinguish any regularities in age group 3 , only the cluster of $X_{10}$ and $X_{8}$ repeats twice (columns $X_{6}$ and $X_{7}$ ). Age group 4 contains only the cluster consisting of $X_{4}, X_{5}$ and $X_{6}$ (columns $X_{4}, X_{5}$ and $X_{6}$ ) and the cluster of two characters, $X_{8}$ and $X_{10}$, with regard to characters $X_{2}$ and $X_{7}$ (column $X_{2}-X_{7}$ ). In age group 5 the cluster of $X_{10}, X_{9}$ and $X_{8}$ repeats with regard to characters $X_{2}-X_{7}$ (columns $X_{2}-X_{7}$ ).

The second possibility is the detection of clusters repeating throughout the successive age groups. In this case none of the previously mentioned 
clusters are preserved whole. It is striking that characters $X_{8}$ and $X_{10}$ occur repeatedly beside each other with regard to several characters, i.e. to $X_{5}, X_{6}$ and $X_{7}$ in age group 2 , to $X_{6}$ and $X_{7}$ in group 3 , to $X_{2}-X_{7}$ in group 4 and to $X_{2}-X_{8}$ in group 5 . At the same time characters $X_{10}$ and $X_{7}$ keep together with regard to characters $X_{1}-X_{6}$ in age groups 1 and 2 . In age group 3 this pair occurs once, with regard to character $X_{b}$, in group 4 four times, with regard to characters $X_{3}-X_{6}$, but in group 5 it is missing entirely.

The third possibility of analysing the distribution of the values of $\alpha$ consists in finding such of these values that they will lie close to each other (differences not exceeding 0.05 ) for different characters with regard to the some character in different age groups. Character $X_{2}$ shows allometry with character $X_{8}$ at the coefficient $\alpha$ equal to 0.547 in age group 1 and with character $X_{6}$ at $\alpha$ equal to 0.580 in group 2. The same character $\left(X_{2}\right)$ has $\alpha$ equal to 0.495 and 0.463 , respectively, with characters $X_{6}$ and $X_{4}$ in age groups 4 and 5 . Character $X_{3}$ is allometrically related to characters $X_{8}$ at $\alpha$ equal to 0.419 in age group 1 and to character $X_{6}$ at 0.425 in age group 2 . In age group 3 character $X_{3}$ shows negative allometry with $X_{6}, \alpha$ being -0.293 and therefore very close to the value -0.295 , which occurs for character $X_{4}$ in age group 5 . Two similar instances can be seen in several other places of the table under discussion.

An examination of the data from the isometric point of view shows the lack of the values of $\alpha$ equal or close to unity. Therefore, in none of the combinations the characters develop strictly isometrically to each other, unless we take into account the values differing from unity at least by more than 10 per cent.

\section{DISCUSSION}

Assuming that the values of $\alpha$ determined for many different parts of an organism form spatial gradients ( $\mathrm{Huxley}, 1932)$, one should keep in mind that these gradients have been determined on the basis of measurements selected in a certain peculiar way. This way results from (1) the choice of points convenient for measurements that can readily be repeated and (2) the designed combination of only some of the characters in allometric pairs. In consequence, it is impossible to construct a general model of growth mechanism of an organism. If we admit according to G o u ld (1966) that the gradient "represents a specific set of potentialities under direct genetic control « (626p.), the presence of fluctuations in the gradient between the same characters in successive stages of growth would indicate the existence of further innate potentialities of controlling these fluctuations. At the moment, the creation 
of a model of the spatial organization of allometric relations, treated as an effect of the action of some controlling patterns, is complicated for two reasons: (1) the instability of gradients in different age groups and (2) the existence of clusters of characters in the nature of gradients.

The clusters of characters with a repeating order in them and stable mutual neighbourhood are determined by the ordering of allometric values in a gradient fashion.

It can be seen from the results obtained that most frequently the characters of which such clusters are composed are not "functionally « connected with each other. The existence of clusters remaining in mutual neighbourhood for even short periods of time is probably conditioned by the biochemical activity of growth-controlling mechanisms, consisting of both stimulation and inhibition. Gradients change incessantly during growth, so that in the case of L. lagurus none of the clusters of characters observed in successive age groups remained complete. With a larger number of age groups the changes in gradients and in the composition of character clusters would probably be less stepwise. The instability of gradients during ontogeny has already been the subject of many considerations, but always with references to the overall size of the organism. Gould (1966) thinks that gradients are innate elements. The fluctuations of gradients in the course of life would rather indicate that they themselves are not inborn and next "distributed « in certain regions of the body, instead what is inborn are the definite patterns of growth regulation. The allometric relationships of characters with each other and the clusters of characters here described might serve merely to construct a model which more or less adequately renders the effects of the action of the coded patterns of the order in which the growth-activating and -inhibiting factors are triggered and cut off. Valuable material for systematic comparisons can be provided, in particular, by the analysis of the growth of the morphologically complex skull with the help of gradients of the coeficient $\alpha$, D'Arcy T h o m p s o n's (1966) method of investigation of shape transformation by observing deformations in the rectangular networks of coordinates superimposed on the drawings of skulls under comparison, is certainly spectacular but unfits for quantitative studies and, in addition, it deals with all changes exclusively in the plane of the skull drawing. In this work our knowledge of the growth of the skull is obtained on the basis of samples and these represent certain states on integration of the morphology of skull. The state of morphological integration and its advancement seem at any moment to be an effect of the balance of two mechanisms, one of which is manifested by correlation and the other by allometry of gradient type. The fluctuations of gradients comprise a component which must be 
allowed for and which results from the method of measuring, for often a measurement is at the same time the sum of dimensions of several cranial bones, each of which may have its own allometry. Morphological integration, based on the correlation of characters and expressed by the "integration coefficient", has, as Ols on \& Miller (1958) have shown, among others, on the skull of the albino rat, two phases of intensity and two of a substantial fall. This is probably associated with changes in the integrating system in the course of growth. The abovementioned authors quite clearly assume the existence of these changes. The integrating systems should therefore be regarded as an important intermediate link in the tranformation of the genetically coded potentialities of development into detailed patterns of growth. The groups of statistically high correlations of some dimensions in the skull of L. lagurus show either a fall in value with age or the maintenance of the values at a constant level, as has been presented in the previous section of this paper. Ols on \& Miller (1958) state that "where the various dimensions increase with divergences in the relative rates, integration tends to be reduced" (174p.). This would mean that the more the correlation of some characters (and therefore the resulting index of morphological integration) decreases, the more the allometry coefficients for these characters should differ from unity. The results of our study confirm this supposition only to a small extent, chiefly because of correlation observed is rectilinear and allometry logarithmic. A greater numerical conformity of the two sorts of data might probably be attained with logarithmic correlation. The gradients that are observed in the clusters occurring here are not »distributed " in the skull according to the anatomical arrangement of the characters and the topography of their mutual neighbourhood. The ranges of fluctuations of the values of $\alpha$ in particular clusters of characters change according to the fact, in relation to which character a given cluster of characters is considered. This would indicate that the pattern of genetic control of allometric growth is composed of many factors. In considering the growth of the rat skull in allometric terms, M os s \& B a e r (1956) found interesting quantitative shifts of gradients appearing both on the dorsal and the ventral side of the skull in some periods of life. These gradients undergo changes to such an extent that they become reversed. The instability of gradients revealed in the present study not only confirms their observations, but also permits the important statement that in dependence on the manner in which the characters are put together in allometric pairs the "localization " of gradients is restricted to only some regions of body or skull (cf. Moss \& B a er, 1956). It is clear that some rapid changes in proportions, occurring with age in the skull and 
perceived by ordinary observation, are brought into prominence by changes in the gradients in the way described by those investigators. These are not, however, the only changes. Many of them cannot be grasped until all the possible combinations of characters in allometric pairs have been performed. M os S \& B a e r's (1956) other interesting statement is that age is not a critical determinant of body proportions. Different races of rats examined by them showed the same changes in gradients (the so-called interphases in allometric curves and shifts) at a different individual age. While comparing the allometry of growth in the mouse, Mc Arthur \& Chaisson (1945) found that all its selective varieties form one allometric tribe, without differing in the constant of allometry. Another fairly general remark emerging from these considerations is that the patterns of allometric growth may be used as characters that allow us to unite different forms of species, identify them or distinguish one from another. The pattern of growth allometry in the albino rat is different. Using the data given by $\mathrm{O} l \mathrm{~s}$ on \& Miller (1958), we calculated the coefficient of allometry in five age groups of the albino rat (Rattus rattus) for several characters of the skull, from a large number of characters selecting only those which we managed to match to the corresponding characters in Lagurus lagurus. In spite of their small number we tabulated them on the some principle of ascending values of $\alpha$. The regularity with which characters $X_{4}$ (maxillary diastema length), $X_{2}$ (zygomatic breadth) and $X_{1}$ (interorbital constriction) with respect to character $X_{8}$ (skull length) preserve the same neighbourhood in relation to each other, i.e. the same numerical order, in all age groups is striking. The allometric relationships of the same characters in L. lagurus show no regularity; the values of $\alpha$ for the same allometric pairs differ significantly between Rattus and Lagurus, which is only natural, because the division into age groups is quite different in these species.

In the light of the considerations carried out hitherto the usefulness of correlations of characters for classificatory purposes seems rather disputable. Fluctuations in the values of the coefficient of single pairs $r$ in different periods of life reduce all attempts at classification to comparisons of the same age groups, which in practice is rarely feasible with indispensable reliability because of the diferences in longevity and growth rate between particular species. On the other hand, the morphological index of integration based on the correlation of characters, proposed by Olson \& Miller (1958), as a generalized measure of the complex of growth processes resulting in the final form of the organism, may play the part of a classificatory character. At any rate, these authors gave much attention to the evolutionary-systematic signifi- 
cance of the coefficient of morphological integration. Allometry dealt with in the clusters of characters or their parts that persist throughout life may be considered to be a character that distinguishes not so much the particular developmental stages of different species as the characteristic paths of their morphological development.

A phenomenon strikingly resembling the here described clusters of characters which maintain their mutual neighbourhood in permutations performed has been described by $\mathrm{Yablok} \mathrm{ov} \mathrm{(1966)} \mathrm{in} \mathrm{his} \mathrm{analysis} \mathrm{of}$ coefficients of variation.

Acknowledgements: We wish to express our sincere gratitude to Professor Zdzisław Pucek, Head of the Mammals Research Institute, Polish Academy of Sciences, at Białowieża for his kind permission to elaborate the collection of skulls in his Institute and valuable critical remarks. We are indebted to Mrs. Halina Kow a lik for her patient co-operation in the technical working-out of the results of mathematical analyses.

\section{REFERENCES}

1. A damczewska K. A., 1959: Untersuchungen über die Variabilität der Gelbhalsmaus, Apodemus flavicollis flavicollis (M el chior, 1934). Acta theriol., 3: $141-190$.

2. Arthur J. W., Mc \& Chaisson L. P., 1945: Relative growth in races of mice produced by selection. Growth 9: 303-315.

3. Gę bczyńska Z., 1967: Morphologic variability of Lagurus lagurus (P a 11 a s, 1773) in laboratory conditions. Acta theriol., 12: 533-543.

4. Gould S. Ji, 1966: Allometry and size in ontogeny and phylogeny. Biol. Rev. 41: $587-640$.

5. Huxley J. S., 1932: Problems of relative growth. Methuen. London.

6. Moss M. L. \& B a e r M. J., 1956: Differential growth of the rat skuil. Growth 25: 107-120.

7. Ols on E. C. \& Mille r R. L., 1958: Morphological integration. The University of Chicago Press: 1-317. Chicago.

8. Simpson G. G., Ro e A. \& Lewontin R. C., 1960: Quantitative zoology. Harcourt, Brace \& Co.: 1-440. New York.

9. Thompson W., D'Arcy, 1966: On growth and form. University Press: 1-345. Cambridge. (ed. J. T. Bonner).

10. Yablokov A. V., 1966: Some problems of studying variability of animals. Žurn. obšč. Biol., 27: 177-190. [in Russian].

Accepted, December 14, 1975.

Institute of Systematic and Experimental Zoology,

Polish Academy of Sciences,

31-016 Kraków, Sławkowska 17. 
Lucjan SYCH i Barbara SYCH

\section{PORZĄDKOWANIE WSPÓECZYNNIKÓW ALLOMETRII DO BADAŃ NAD GRADIENTAMI WZROSTU}

\section{Streszczenie}

Celem pracy były analiza wzrostu czaszki w terminach allometrii i korelacji. Hodowany Lagurus lagurus stanowił dogodny materiał do badań, ponieważ zna:e były daty urodzenia i śmierci. W okresie wzrostu organizmu większość cech podlega zmianom naogół w nierównym tempie. Nierównomierność tempa zmian uchwytna jest przy śledzeniu odchyleń od prostej allometrii wzrostu. Swoistość allometrycznych zmian cech bywa konwencjonalnie badana poprzez znajdywanie krzywolinijnej zależności wybranych cech od jednej ustalonej. Tu zaproponowano odmienny sposób traktowania odchyleń od prostej allometrii, polegający na analizie wszystkich możliwych allometrycznych kombinacjach cech ze sobą.

Współczynnik allometrii $\alpha$ obliczano ze stosunku $k_{i}: k_{k}$, gdzie $k_{i}$ i $k_{k}$ są współczynnikami wzrostu dwóch cech $i$ oraz $k$ w tej samej grupie wiekowej. Wartości analizowano w matrycach, które budowano według zasady zestawiania jednej cechy z pozostałymi aż do wyczerpania poprzez kolejne permutacje wszystkich możliwych kombinacji w pary. W obrębie każdej grupy permutacji wartości $\alpha$ ustawiano według porządku rosnącego. Odpowiadające wzrastającym a poszczególne cechy porządkowały się w pewien charakterystyczny sposób w każdej z tabel. Wzajemne mianowicie sąsiedztwo niektórych cech pozostawało niezmienione niezależnie od permutacji. Uporządkowane cechy tworzą mniejsze lub większe zespoly, charakteryzujące się zachowaniem tego samego wzajemnego sąsiedztwa cech. Prześledzenie zespołów cech powtarzających się poprzez kolejne permutacje oraz przez grupy wiekowe wykazało, że wspomniane zespoły nie zawsze zachowują się w całości. Równocześnie stwierdzono, że żadna kombinacja cech nie rozwija się idealnie izometrycznie względem siebie. Zespoły cech o powtarzającym się wzajemnym sąsiedztwie w zespołach wyznaczone są przez gradientowe uporządkowanie wartości allometrycznych. Istnienie zespołów cech we wzajemnym sąsiedztwie przez krótikie nawet okresy czasu warunkowane jest prawdopodobnie działaniem mechanizmów sterujących wzrostem, złożonych zarówno ze stymulowania jak i hamowania. Gradienty w takim ujęciu zmieniają się ustawicznie w czasie wzrostu, tak, że żaden ze zespołów cech śledzonych w kolejnych grupach wiekowych nie zachowuje się w przypadku L. lagurus w całości. Praca zawiera sugestię możliwości wykrywania gradientów w trakcie wzrostu organizmów na zasadzie opisanego sposobu badania allometrii.

Korelacje porównywano zbierając w macierz współczynniki $r$ obliczone dla wszystkich możliwych kombinacji cech parami (,każda z każdą”), we wszystkich grupach wiekowych. Wartości $r$ rozpatrywane były z punktu widzenia trwałości związków cech w ciągu życia, lub braku związku w ogóle. Za charakterystyczne właściwości powyższych układów należy uznać: (1) wysoką korelację długości górnej diastemy z długością czaszki przy równoczesnym braku związku długości dolnej diastemy z długością czaski; (2) wyraźną korelacją długości szeregów zębowych z dlugością czaszki; (3) całkowity brak związku długości szeregów zębowych z długością diastemy, zarówno w szczęce jak i w żuchwie; (4) zróżnicowanie układów wysoko skorelowanych na układy o korelacji utrzymującej się przez bardzo długi czas i na takie, w których korelacja zanika lub maleje istotnie w drugiej lub trzeciej grupie wiekowej. 